\title{
III Konferencja Naukowa Problemy zdrowia reprodukcyjnego kobiet Wrocław, 8 listopada 2019 roku (Aleksandra Szlagowska)
}

8 listopada 2019 r. w Zakładzie Humanistycznych Nauk Wydziału Farmaceutycznego Uniwersytetu Medycznego we Wrocławiu odbyła się III edycja konferencji pt. „Problemy zdrowia reprodukcyjnego kobiet”. W interdyscyplinarnej konferencji udział wzięło kilkunastu naukowców reprezentujących polskie i zagraniczne ośrodki naukowe. Podczas konferencji w 2016 r. inicjującej tę problematykę zastanawialiśmy się nad kwestią samej definicji zdrowia reprodukcyjnego, która jest dla niektórych środowisk dość kontrowersyjna. Celem poznawczym obecnej edycji konferencji było opracowanie monografii zbiorczej związanej z problemami zdrowia reprodukcyjnego kobiet, w której autorzy poszczególnych referatów pogłębiali liczne wątki związane $\mathrm{z}$ tym tematem. Stąd w programie znalazły się referaty dotyczące m.in.: historii problemów zdrowia reprodukcyjnego kobiet od czasów starożytnych do połowy XX w.; regulacji prawnych dotyczących aborcji eugenicznej; pronatalizmu i populacjonizmu, ale też eugeniki jako elementów polityki społecznej; zmian w historycznym modelu rodziny oraz medykalizacji okresu rozrodczego kobiet.

Konferencja podzielona została na dwie sesje, pierwsza dotyczyła Społeczno-kulturowych, religijnych i prawnych aspektów zdrowia reprodukcyjnego kobiet, druga zaś Historycznych i medycznych aspektów zdrowia reprodukcyjnego kobiet. W pierwszej części znalazł się m.in. referat Transseksualizm jako problem egzystencjalny, w którym prof. Jarosław Barański poruszał wątki odnoszące się do zdefiniowania przedstawianych zagadnień, zaprezentował również statystyki światowe i polskie. Przede wszystkim jednak skoncentrował się na problemie nieumiejętności dostosowania się osób po zmianie płci do otaczającego ich świata i w tym kontekście poruszające są przypadki samobójstw popełnianych przez takie osoby.

Referat dr. Mateusza Dąsala z Zakładu Humanistycznych Nauk Wydziału Farmaceutycznego Uniwersytetu Medycznego we Wrocławiu pt. Bioetyczne dylematy „projektowania” dzieci dotyczył wyzwań 


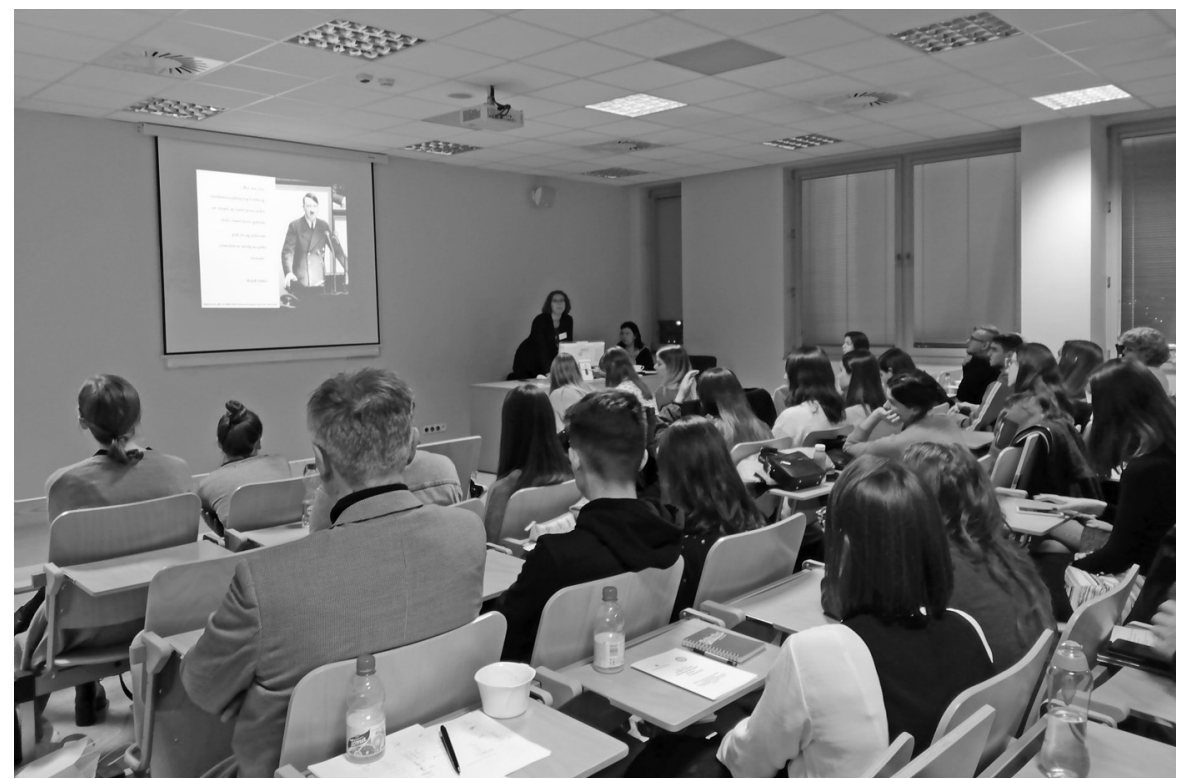

Uczestnicy konferencji naukowej, fot. A. Szlagowska

bioetycznych związanych z coraz bardziej aktualnym problemem genetycznych technologii reprodukcyjnych człowieka. Realna sytuacja, w której potencjalni rodzice nie mają nic, z biologicznego punktu widzenia, wspólnego ze swoim potomkiem (handel zarodkami, surogatki etc.), stawia pytanie o współczesny status rodzicielstwa nie tylko przed teoretykami, lecz także coraz częściej przed współcześnie żyjącym ludźmi. $Z$ drugiej strony tzw. turystyka reprodukcyjna (np. matki zastępcze wynajmowane w Indiach czy na Ukrainie) każe nam zastanowić się nad etycznym wyzwaniem w skali globalnej. Autor wskazał również dylematy, jakie omawiany problem stawia przed systemami religijnymi, które muszą, a przynajmniej powinny, przedstawić stanowisko wobec nowych, bezprecedensowych zjawisk.

Jak można było usłyszeć w trakcie obu wystąpień, kwestie związane ze współczesnymi problemami zdrowia reprodukcyjnego, ogólnie definiowanym, nie tyle dogoniły nas, ile w pewnym sensie - przegoniły. Wzbudziły też wśród słuchaczy ożywioną dyskusję.

Sesja historyczna rozpoczęła się od czasów prehistorycznych, których dotyczył referat dr. hab. Leszka Żuka, natomiast w czasy starożytnej Grecji i Rzymu przeniosły nas Panie reprezentujące Uniwersytet im. Adama Mickiewicza w Poznaniu - dr hab. prof. UAM Anna Tatarkiewicz oraz dr Anna Lasek. Dr Krzysztof Prętki z Poznania 


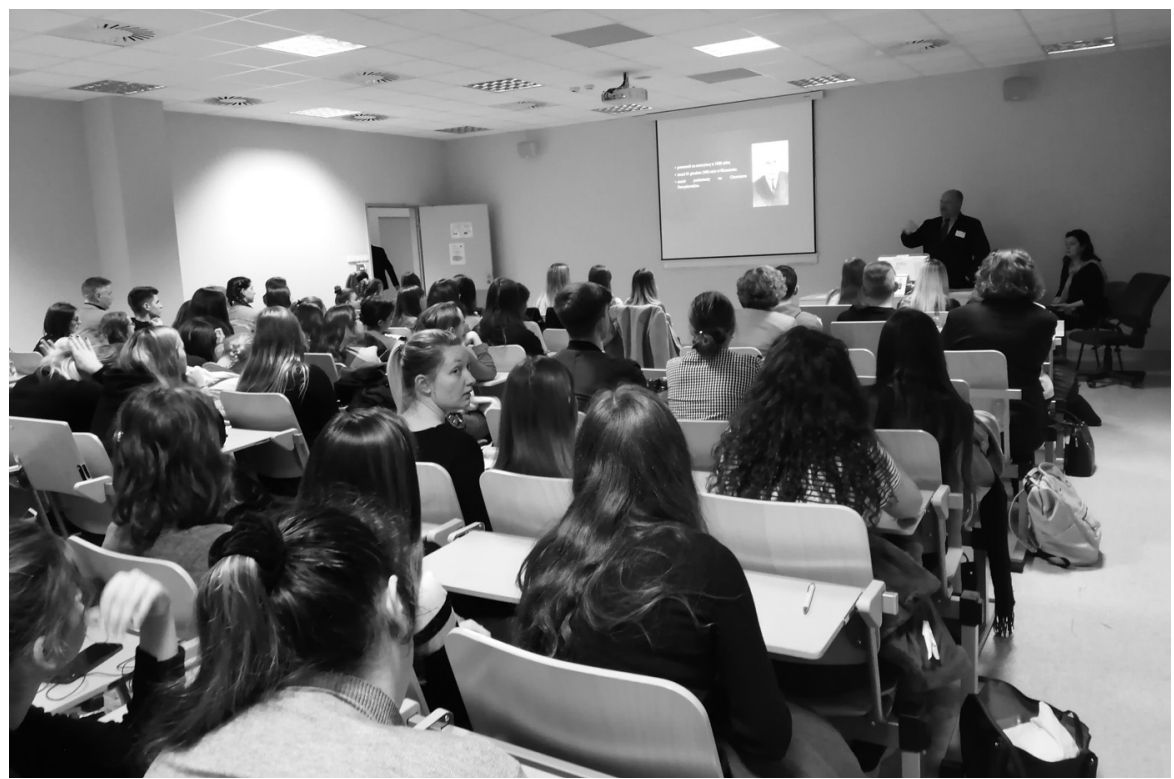

Uczestnicy konferencji naukowej, fot. A. Szlagowska

zaprezentował sylwetkę jednego z czołowych polskich eugenistów w referacie Problematyka przerywania ciaży, sterylizacji $i$ kastracji w ujęciu Wiktora Grzywo-Dąbrowskiego (1885-1968). Niejako na dwóch biegunach znalazły się wystąpienia dr hab. Anity Napierały pt. Bez macierzyństwa - nie ma kobiety! Przyczyny i sposoby leczenia bezpłodności kobiet w pierwszej połowie XX wieku - o problemie bezpłodności i sposobach leczenia z pierwszej połowy XX w. oraz referat Problemy zdrowia reprodukcyjnego kobiet - byłych więźniarek obozów koncentracyjnych na łamach „Przegladu Lekarskiego - Oświęcim" (1961-1991) dr Marii Ciesielskiej, która zaprezentowała m.in. mocno kontrowersyjne eksperymenty, jakich dopuszczali się niemieccy lekarze na kobietach pochodzenia żydowskiego w nazistowskim obozie Auschwitz-Birkenau, które doprowadzić miały do „odkrycia” skutecznej metody pozbawienia płodności.

Referat Aleksandry Szlagowskiej Medyczne konsekwencje „grzechu tajemnego" - XIX $i \mathrm{XX} w$. koncentrował się na analizie medycznych konsekwencji masturbacji jako ogromnego zagrożenia dla rozwoju zdrowotnego młodzieży. Dopiero w drugiej połowie XVIII w. zaczęto ten problem ujmować również w kontekście medycznym. We wcześniejszym okresie onanizm traktowany był głównie jako występek przeciwko moralności, w średniowieczu i renesansie teologowie 
ujmowali onanizm w kategorii grzechów „przeciwko naturze” wraz z sodomią czy coitus interruptus.

Konferencję zakończyła dr Gabriela Gańczarczyk z Uniwersytetu w Pardubicach, która zaprezentowała niezwykle ciekawy artykuł poświęcony problemowi aborcji w Czechosłowacji w latach 1948-1991. Nieznane nam dotychczas fakty pozwoliły dostrzec, jak odmiennie na te zagadnienia patrzono w różnych krajach bloku wschodniego.

Uczestnicy oraz przybyli na konferencję słuchacze mieli niepowtarzalną okazję wysłuchać wielu interesujących wystąpień, które ukażą się w formie publikacji pt. Problemy zdrowia reprodukcyjnego kobiet. 